\title{
Accounting information technology and village finance management in Indonesia
}

\author{
Rindu Rika Gamayuni* \\ Faculty of Economics and Business, University of Lampung, Lampung, Indonesia
}

\author{
Keywords \\ Accounting information \\ Management accounting \\ IQ \\ Accountability \\ Transparent \\ Participative
}

Received: 4 September 2019

Accepted: 6 November 2019

Published: 12 February 2020

\begin{abstract}
The purpose of this paper is to examine (1) The effect of accounting information technology on management accounting Information Quality (IQ), and (2) The effect of management accounting IQ on village finance management, and (3) The effect of Act of Republik Indonesia (RI) Number 6/2014 on village finance management. This study population uses the villages in Indonesia. The questionnaire as primary data is statistically processed and tested using Structural Equation Model Partial Least Square (SEM-PLS). This study provides empirical evidence that the implementation of accounting information technology has a positive and significant effect on management accounting IQ. The $\mathrm{v}$ accounting information technology has a positive and significant effect on village finance management. The more quality of the information technology application generates, the better the village finance management (transparent, accountable, participative). The implementation of Act Number 6/2014 about The Village has a positive and significant effect on village finance management. The implementation of Act Number 6/2014 is reflected by being implemented the strategy, organization, movement, leadership, and reasonable control so that it will create transparent, accountable, and participative village finance management. This result implies that villages must implement a high-quality management accounting information system to produce quality information to improve village finance management. The novelty of this research is to give empirical proof about information technology and quality of management accounting in the village as the public sector, which is essential to create transparent, accountable, and participative village finance management.
\end{abstract}

(C) 2020 The Author(s). Published by TAF Publishing.

\section{INTRODUCTION}

The reformation of the financial information system in this new public financial management era is an essential element in improving management or and decision-making in government institutions (Guthrie, Olson, \& Humphrey, 1999; Ilias, Razak, \& Rahman, 2015). The village government needs a system that can produce financial statements and other financial information more comprehensively, includes information on village finance position, financial performance condition, and village accountability. This technology information system is called the Village Finance Information System (Siskeudes). BPKP, in this case, The Supervisory Deputy of The Local Finance Organization, has established the development of the Village Finance Information System (Siskeudes) as an activity to support the achievement of a good village finance management (trans- parent, accountable, participative).

Act Number 6/2014 about The Village puts transparency and participation as an important aspect of a development change at the village level. With the funding status sourced from the State Budget (APBN) and the Regional Government Budget (APBD), the village governance becomes an obligatory subject in the provision and implementation of information disclosure. Act Number 6/2014 and its implementation regulation have mandated the village government to be more independent in managing government and various resources owned, including the village finance management. In 2015, the central government allocated the village funds 20,7 trillion rupiahs for 74.093 villages, while in 2016, the fund allocates was 46,9 trillion rupiahs for 74.754 villages spread across Indonesia. The Village Fund will continue to increase for more than 1 billion per village by 2017

* corresponding author: Rindu Rika Gamayuni

†email: rindu.gamayuni@yahoo.com 
(https://bit.ly/2zDhFJo). There are other village revenues, such as the Village Fund Allocation, Tax Revenue/Retribution Funds, and Grant Loan from province/regency/local government. The village government must be able to apply the principle of accountability in village finance management, in which all of the village government activities must be accountable to its people following the regulation so that it will create good village governance. A large amount of village fund requires the accountable village finance management, both in the process of implementation, administration, and reporting. This study aims to obtain empirical evidence of the effect of information technology (village management accounting application or Siskeudes) on IQ of village management accounting, and the effect of the implementation of information technology and Act Number $6 / 2014$ on village finance management.

\section{LITERATURE REVIEW AND HYPOTHESES DEVELOP- MENT}

The Implementation of Information Technology of Village Management Accounting

Warren, Reeve, and Fess (1999) defined the accounting information system as a method and procedure for collecting, classifying, summarizing, and reporting information about financial statements and operation of an organization. While Chia (1995) defined, the management accounting information system was a system that can facilitate supervision by making reports and creating a real action of the performance evaluation from each component in an organization. Village Finance Information System (Siskeudes), a form of management accounting information system, is a technology-based application system that is developed to support the accountability achievement for a village government. This application is expected to assist local government in preparation for planning and budgeting, implementation, and administration of APBD and the accountability of APBD (www.BPKP.go.id). DeLone and McLean (1992) stated that the success determinant factors of information systems were system quality, IQ, service quality, usage, and user satisfaction. System quality is a characteristic required by an information system, for example, user ease, system flexibility, reliability, comprehensibility, system features, sophistication, and the number of responses. IQ is relevance, comprehensibility, accurate, conciseness, completeness, timeliness, and usability. Service quality is a supporting quality received by the system users from the organization to information technology supporting personnel, for example, responsiveness, accuracy, reliability, technical competence, and empathy of the IT personnel staff. Use is the degree and the way employees and consumers use the capabilities of an information system. For example, the amount, the nature, the suitability, the extent, and the purpose of use. User Satisfaction is the level of user satisfaction on reports, web sites, and support services. For example, the broader use of an instrument attribute to measure information satisfaction.

\section{The IQ of Management Accounting}

McLeod (2007) stated that the IQ of management accounting had relevance, accuracy, and completeness dimensions. Relevance means there is a conformity of information produced with the required. Accuracy means that the information generated reflects the actual situation. Completeness means that the information provided must be complete. Village finance information system (Siskeudes) is an organizational control mechanism and an effective tool in providing useful information to predict the possible consequences of the activities performed. Chenhall and Morris (1986) found empirical evidence of useful information characteristics, which are: (1) broad scope, (2) aggregation, (3) integration, (4) timeliness. Broadscope has three sub-dimensions: focus, quantification, and time. Aggregate is a summary of information by function, period, and decision model. Integration provides a means of coordination between segments in sub-units or between sub-units in an organization. The complexity and interdependent of subunits will be shown in the integrated information of SIAM (Chenhall \& Morris, 1986). Integrated information provides a coordinating role in a variety of decisions in highly decentralized organizations. Integrated information is also seen as a good trigger for managers (government) and indicates that this information contributes to performance improvement (Chia, 1995; Eze, 2017). Timeliness has two subdimensions: reporting frequency and reporting speed. Frequency relates to how often data is provided to managers. Speed is related to the interval of time between the need and the availability of information.

\section{The Implementation of Act Number 6/2014 About The Village}

The implementation of Act Number 6/2014 about The Village contains the village fund. The regulation of village finance is based on Article 71-75 of Act Number 6/2014. The implementation management model, according to Riant (2004), was described as the implementation of policies in the management context within the organizing-leadingcontrolling framework. So, when the system is made, then the next task is to organize, implement the leadership, lead 
the implementation, and control the application.

\section{Village Finance Management}

According to The Regulation of The Minister of Home Affairs (Permendagri) Number 113/2014, Village Finance Management is the whole activity which includes planning, implementation, administration, reporting, and village finance accountability. The village government should use village finance management principles that are managed based on transparent, accountable, participative, discipline, and budget discipline principles. The village finance management is maintained within one budget year from January 1 to December 31. Article 4, clause 7 of Permendagri Number 13/2006 about Guidelines on Local Finance Management, states that transparent is a principle of openness that allows the public to know and gain access to information as wide as possible on local finance. Accountability is an obligation to give accountability or answer and explain the performance and action of a person/legal body/organization's leader to a party who has the right for information or accountability. Participation means that every citizen has a voice in decision-making, either directly or through the intermediation of the legitimate institution representing his/her interests (Negara, Keuangan, \& Pembangunan, 2000; Tsai \& Tsai, 2017).

The Implementation of Accounting Information Technology and the Management Accounting IQ

O'brien and Marakas (2005) argued that information systems with computers caused managers to obtain information quickly and provide more reports. (Jingsi, 2017; Prudhomme, 1991) disclosed that information technology facilitates decentralized and decision-making activities. Prudhomme (1991) also stated that the implementation of information technology would improve the quality characteristics of the management accounting system (broad scope, timeliness, aggregated, and integrated information). The implementation of an accounting information system is essential in preparing quality management accounting information (Mancini, Vassen E, \& Dameri, 2013). Based on the theory and previous research results, this leads to the following hypothesis.

H1: The Implementation of Accounting Information Technology has a positive effect on the management of accounting IQ.

\section{The Management Accounting IQ and Village Finance Management}

The function of the accounting information system is not only to process data transactions into financial statements but also as a means for controlling the financial statements to produce more reliable financial statements (Mancini et al., 2013). The quality of management accounting information system can provide more quality (transparent, accountable, participative ) finance management, not only limited to the private sector but also applicable to the government sector (Abdallah, 2013). Local government is required ready to utilize accounting information systems to build transparency in offering data to partners about the financial related of local government (Chalu \& Kessy, 2011; Crespo, Ripoll, Tamarit, \& Valverde, 2018). Ramdhani (2015) proved that there was an effect of the quality of management accounting information system on financial reporting quality. So did Abdallah (2013) found the use of accounting information system had an impact on financial management in Jordan.

Furthermore, Ismail and King (2014) proved that the wellrun management accounting information system would generate quality financial management. Based on the theory and previous research results, this leads to the following hypothesis.

H2: The management accounting IQ has a positive effect on Village Finance Management.

\section{The Implementation of Act Number 6/2014 and Village Finance Management}

Village Fund Allocation policy can increase people's participation in village development. The implementation of Act Number 6/2014 about The Village and other implementing regulations are intended in the hope that village fund finance management can be well and adequately realized, just like in transparent, accountable and participative aspects. At the state level that has undergone reforms by implementing new public management. McPhee (2006) in the Australian government stated that many practitioners gained benefit from budgeting and financial reporting, like more efficient and effective managing programs, which could increase accountability. Galera and Bolívar (2012) in Spain proved that the implementation of accrual base accounting will increase financial accountability. This leads to the following hypothesis.

H3: The implementation of Act Number 6/2014 has a positive effect on village finance management (transparent, accountable, and participative). 


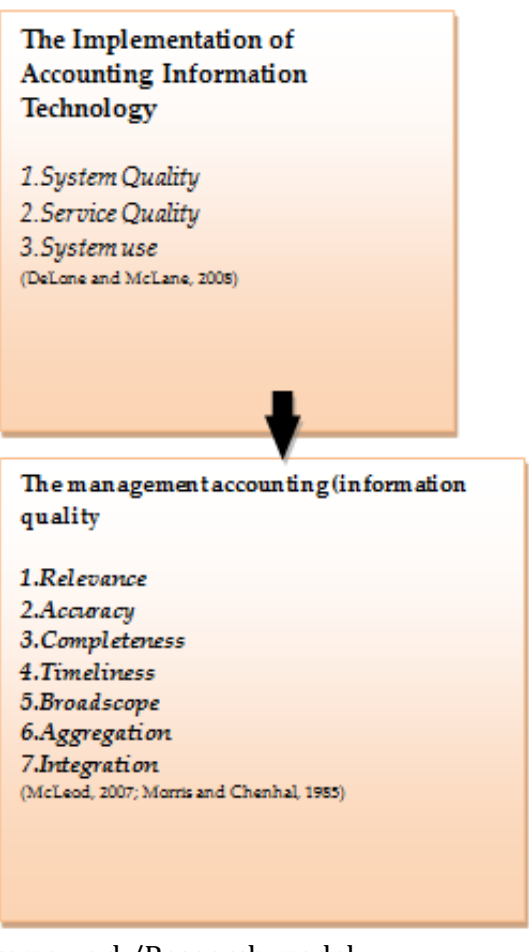

FIGURE 1. The framework/Research model

\section{RESEARCH METHODOLOGY}

Data analysis using Structural Equation Modeling (SEM) Partial Least Square (PLS). Primary data were obtained through questionnaires and interviews. The population was all of the villages in Indonesia. The sample determination used purposive sampling with the criteria of the regen-

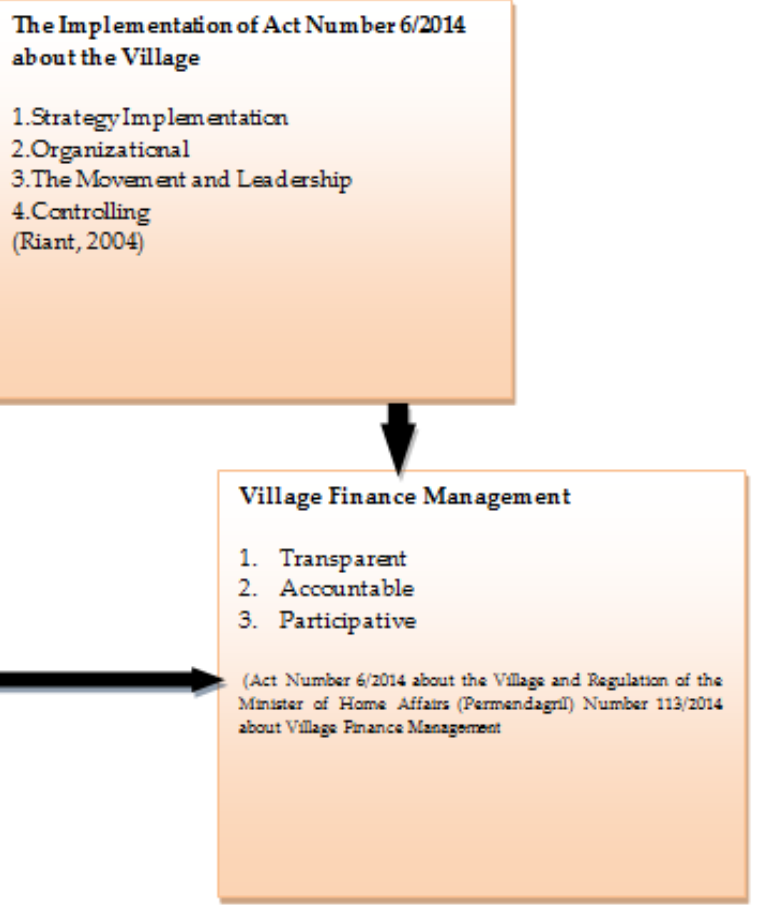

The Implementation of Act Number 6/2014

bout the Village

Organizaticnal

Riant, 2004)

TABLE 1. Variable measurement

\begin{tabular}{|c|c|c|}
\hline \multirow{2}{*}{$\begin{array}{l}\text { Variable } \\
\text { The Implementation of Informa- } \\
\text { tion Technology (VT) } \\
\text { (Delone \& McLean, 2003) }\end{array}$} & \multirow{2}{*}{$\begin{array}{l}\text { Dimension } \\
\text { 1. System quality (Delone \& } \\
\text { McLean, 2003) }\end{array}$} & \multirow{2}{*}{$\begin{array}{l}\text { Indicator } \\
1.1 \text { The system easiness. }\end{array}$} \\
\hline & & \\
\hline (Delone \& McLean, 2003) & $\begin{array}{l}\text { 2. Service quality (Delone \& } \\
\text { McLean, 2003) }\end{array}$ & $\begin{array}{l}2.2 \text { The system's ability to re- } \\
\text { spond to needs. } \\
\text { 2.3 Timeliness in process. }\end{array}$ \\
\hline & $\begin{array}{l}\text { 3. System use (Delone \& McLean, } \\
\text { 2003) }\end{array}$ & 3.1 The usage level. \\
\hline & & 3.2 The usage purpose. \\
\hline The management accounting IQ & 1. Relevance & $\begin{array}{l}\text { 1. The information produced and } \\
\text { needed is appropriate. }\end{array}$ \\
\hline & 2. Accuracy & $\begin{array}{l}\text { 2. The information produced re- } \\
\text { flects the actual situation. }\end{array}$ \\
\hline & 3. Competencies & $\begin{array}{l}\text { 3. The information must be com- } \\
\text { plete. }\end{array}$ \\
\hline $\begin{array}{l}\text { (Chenhall \& Morris, 1986; } \\
\text { McLeod, 2007) }\end{array}$ & 4. Timeliness & $\begin{array}{l}\text { 4. The information is available } \\
\text { when needed. }\end{array}$ \\
\hline & 5. Broad scope & $\begin{array}{l}\text { 5. The information can predict a } \\
\text { future event. }\end{array}$ \\
\hline & 6. Aggregation & $\begin{array}{l}\text { 6. The information is brief yet } \\
\text { complete. }\end{array}$ \\
\hline & 7. Integration & 7. The information is integrated. \\
\hline
\end{tabular}

cies that received the village fund program from the government and had implemented Siskeudes (11 regencies). The number of samples consists of 24 villages, with a total number of respondents as many as 95 people. The respondents were village chiefs, village secretaries, and village treasurers. 
TABLE 1. Continue.

\begin{tabular}{|c|c|c|}
\hline Variable & Dimension & Indicator \\
\hline \multirow[t]{5}{*}{$\begin{array}{l}\text { The implementation of Act Num- } \\
\text { ber } 6 / 2014 \text { (IAV) }\end{array}$} & 1. Strategy Implementation & 1.1 Management strategy \\
\hline & & 1.2 Performance \\
\hline & 2. Organizational & $\begin{array}{l}\text { 2.1 Management activities } \\
\text { 2.2 Village bureaucracy } \\
\text { 2.3 Rules compliance }\end{array}$ \\
\hline & 3. Movement and Leadership & $\begin{array}{l}\text { 3.1 Systematic } \\
\text { 3.2 Organization movement } \\
\text { 3.3 Management performance }\end{array}$ \\
\hline & 4. Controlling & $\begin{array}{l}\text { 4.1 Team controlling } \\
4.2 \text { Policy controlling }\end{array}$ \\
\hline \multirow[t]{4}{*}{$\begin{array}{l}\text { Village } \\
\text { Finance } \text { Management } \\
\text { 2015) }\end{array}$} & 1. Transparent & 1.1 Information \\
\hline & & 1.2 Transparent \\
\hline & 2. Accountable & $\begin{array}{l}\text { 2.1 Management } \\
\text { 2.2 Implementation } \\
\text { 2.3 Controlling }\end{array}$ \\
\hline & 3. Participative & $\begin{array}{l}\text { 3.1 Village deliberation } \\
\text { 3.2 People's self-help }\end{array}$ \\
\hline
\end{tabular}

\section{RESULTS AND DISCUSSION}

Based on the validity test, all variables were valid, as evidenced by the AVE values were higher than 0,4 . This means that information contained in all dimensions and indicators had been represented in latent variables. The latent variable had a reliability value of more than 0,6 (recommended score), which meant that all dimensions and indicators were consistent. By using the PLS analysis method, it produced the path diagram model, as shown in Figure 2 below:

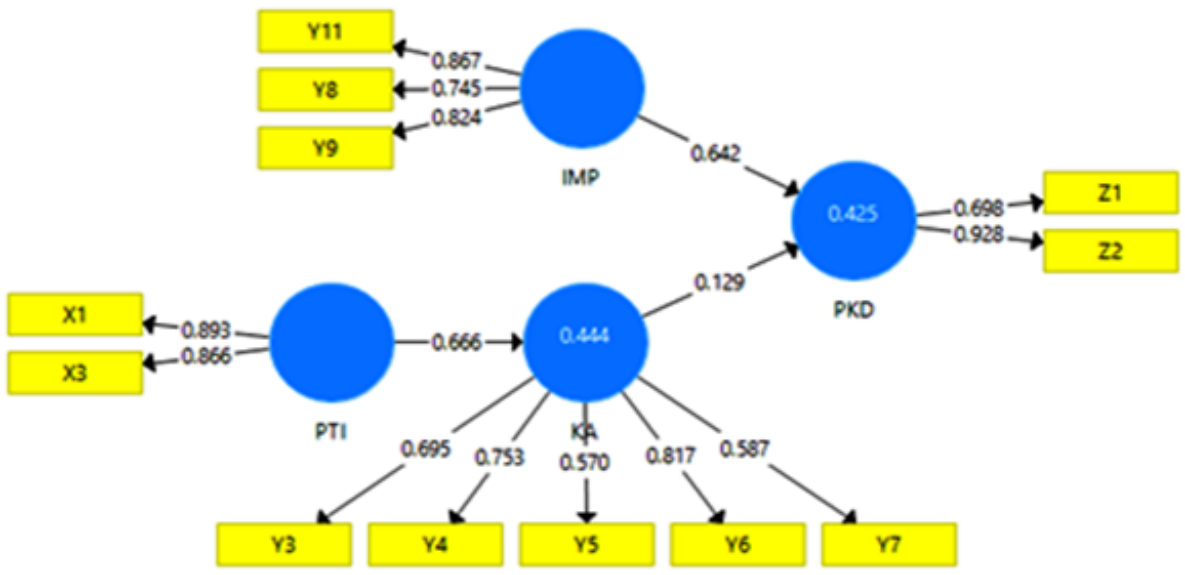

FIGURE 2. Structural model coefficient standard

TABLE 2. The Effect of The Implementation of Village Finance Management Technology System (VT), The IQ of Village Management Accounting (IQ), The Implementation of Act Number 6/2014 (IAV) on VFM

\begin{tabular}{lllll}
\hline \hline Effect & Path Coefficient & $\boldsymbol{t}$ Value & $\boldsymbol{p}$ Value & Ha \\
\hline $\mathrm{VT} \rightarrow$ IQ & 0.666 & 1.741 & $0.082^{* *}$ & Supported \\
$\mathrm{SIQ} \rightarrow$ VFM & 0.129 & 14,086 & $0.000^{*}$ & Supported \\
$\mathrm{IAV} \rightarrow$ VFM & 0.642 & 10.878 & $0.000^{*}$ & Supported \\
\hline \hline
\end{tabular}

* Significant at the $5 \%$ alpha level

** Significant at the $10 \%$ alpha level 
The $R^{2}$ for the first regression model of this model study is 0,444 , which means that the variable of the implementation of information technology (PTI) can explain the Audit Quality (KA) for $44.4 \%$. $R^{2}$ for the second regression model is 0,425 (model is at a moderate level or good enough) means that the Audit Quality (KA) variable and the implementation of Act Number 6/2004 can explain the variable of Local Finance Management (PKD) equals to $42,5 \%$. The test result of the first hypothesis showed that there was a significant effect from implementing information system technology (siskeudes) on IQ of village finance management (siskeudes) at a significant level of $10 \%$, with a path coefficient of 0,666 . The result of the second hypothesis test showed that there was a significant effect from the IQ of village finance management (siskeudes) on village finance management at a significant level of $5 \%$, with the path coefficient 0,129 . The result of the third hypothesis test showed that there was a significant effect from the implementation of Act Number 6/2014 on village finance management at a significant level of $5 \%$, with the path coefficient of 0.642 .

There is a positive and significant effect from the implementation of the technology of the village financial management information system (siskeudes) on IQ of village finance management (siskeudes) at a significant level of $10 \%$. The better the implementation of siskeudes, the more increase the quality of information generated by siskeudes. In line with O'brien and Marakas (2005) which stated that information systems with computers caused managers to obtain information quickly and provide more reports (timeliness, completeness, broad scope, aggregation, and integration). This result is also in line with Prudhomme (1991), who disclosed that the information technology facilitated in the management of decentralization and decision-making activities. Prudhomme (1991) also stated that the implementation of information technology would improve the quality characteristics of management accounting systems (broad scope, timeliness, aggregated, and integrated information). The Implementation of an accounting information system is essential in preparing quality management accounting information (Sačer, Ivana, \& Oluić, 2013).

Based on this study result, the dimensions that represent the variable of the accounting information technology is System Quality and System Use, whereas the dimension of System Service can not. This indicates that the success of the implementation of Siskeudes requires System Quality (ease of use and reliability of the system) and System Use (level and purpose of use). The System Service (the ability of the system to respond to the needs and timeliness in processing data) has not been contributed to the implemen- tation of Siskeudes because Siskeudes is a very new applied running system. The people, especially the village apparatus as village finance managers still need to adapt to this Siskeudes so that the system can perform its useful function to respond to the people's needs and process on time. There is a positive and significant effect of the IQ of village finance management accounting (Siskeudes) on village finance management at a 5\% significance level. The better quality of information generated by Siskeudes, the better village finance management. This is in line with Mancini et al. (2013), who stated that the accounting information system roled as a control tool to produce reliable financial statements. So did Abdallah (2013) indicated that the quality of management accounting information systems could provide a better (transparent, accountable, participative) finance management.

The result of this study supports Ismail and King (2014) and Ramdhani (2015) that proved there was an effect of accounting information system quality on the quality of financial reporting. So did Abdallah (2013) found the use of accounting information systems had an effect on finance management in Jordan.

Based on the result of this study, the management accounting IQ can be reflected in the dimensions of completeness, timeliness, broad scope, aggregation, and integration. Still, on the other hand, dimension of relevance and accuracy are not valid enough to reflect the quality of information produced by Siskeudes. This indicates that the information provided by Siskeudes is the quality information, which has characteristics: complete, available when needed (timeliness), able to estimate future events (broad scope), aggregated, and ready to integrate. Relevance means that the information produced is appropriate with the information required), and the accuracy (information provided reflects the actual situation) in this study can not reflect the quality information from Siskeudes. It is because there are still many village apparatus that do not understand Siskeudes' decision-making, and also, the information produced does not reflect the actual situation.

There is a positive and significant effect of the implementation of Act Number 6/2014 about Village Funds on village finance management at a $5 \%$ significance level. The better implementation of Act Number 6/2014, the better the village financial management (accountable, transparent, and participative). The dimensions/indicators of the implementation of Act Number 6/2014 are strategies, organizational, movement, leadership, and control. The Village Fund Allocation policy as a substitute for Village Development Fund Policy (DPD/K) can increase people's participa- 
tion in village development. It can be seen from the active villager's participation in the implementation of the Village Fund Allocation Policy. The prevailing regulations should implement a policy that has been issued by the government. Implementation is intended that the objectives and targets in the policy are achieved even though there are some obstacles. Based on Article 71 of Act Number 6/2014, it states that village finance is all the village's rights and obligations that can be valued with money and everything in the form of money and goods related to the rights and obligations of the village. These rights and obligations result in income, expenditures, financing and village finance management. The Implementation of Act Number 6/2014 about The Village and other implementing regulations are intended to ensure that village fund finance management can be realized properly, as well as transparent, accountable, and participative. Crespo et al. (2018) provided empirical evidence that the implementation of financial management had a positive effect on the quality of financial statements in Bengkulu Province. So did Fahri (2017) proved that the implementation of village fund policies improved the village finance management. The resulting study by Jorge de (de Jesus \& Eirado, 2012) shows that accounting information affects accountability in the public sector and ready to expand responsibility. In some countries, there has been reformation by implementing new public management. The result of ? (?) in Australia and Galera and Bolívar (2012) in Spain suggested that many practitioners gained benefit from budgeting and financial statement reformation, like managing program more efficiently and effectively so that it would improve financial accountability.

\section{CONCLUSION AND IMPLICATIONS}

Based on the phenomenon, hypothesis, and the result of descriptive and statistical analysis, the conclusion can be drawn as follows:

1. The implementation of accounting information technology (Siskeudes) has a positive and significant effect on the accounting IQ in the village in Indonesia. Siskeudes has been quite well implemented (in terms of system quality, service quality, and system usage), so it will improve the quality of information generated by Siskeudes (relevant, accurate, complete, timeliness, predictable, aggregate, and integrated information). However, based on this study result, the quality of service is not valid enough to measure the implementation of Siskeudes. Neither the relevance dimensions/indicators nor accuracy are accurate enough as dimensions/indicators to measure the quality of information generated by Siskeudes. This is because Siskeudes is a new system. Most villagers apparatus have not understood and mastered the use of Siskeudes. This causes the benefit of Siskeudes has not been obtained in village finance management.

2. The management accounting IQ has a positive and significant effect on village finance management. The more quality of information that Siskeudes produces (relevant, accurate, complete, timely, predictable, aggregate, and integrated), the better village finance management (transparent, accountable, participative).

3. The implementation of Act Number 6/2014 about The Village has a significant and positive effect on village funds management. The implementation of Act Number 6/2014 reflects from the implementation of strategy, organizational, movement, leadership, and proper controlling so that it will create a transparent, accountable, and participative village finance management.

The management accounting IQ can be reflected in the dimensions of completeness, timeliness, broad scope, aggregation, and integration, according to the findings of this study. However, the dimensions of relevance and accuracy are insufficient to reflect the quality of information produced by Siskeudes. This indicates that the information provided by Siskeudes is of high quality, as it is complete, available when needed (timeliness), capable of estimating future events (broad scope), aggregated, and ready for integration.

\section{REFERENCES}

Abdallah, A. A. J. (2013). The impact of using accounting information systems on the quality of financial statements: Submitted to the income and sales tax department in Jordan. European Scientific Journal, 1(7), 41-48.

Chalu, H., \& Kessy, S. (2011). Accounting information systems and governance issues in local government authorities in Tanzania. London, UK: Henry Chalu and Severine Kesy.

Chenhall, R. H., \& Morris, D. (1986). The impact of structure, environment, and interdependence on the perceived usefulness of management accounting systems. Accounting Review, 5(7), 16-35.

Chia, Y. M. (1995). Decentralization, Management Accounting System (MAS) information characteristics and their interaction effects on managerial performance: A Singapore study. Journal of Business Finance \& Accounting, 22(6), 811-830. doi:https://doi.org/10.1111/j.1468-5957.1995.tb00390.x 
Crespo, C., Ripoll, V., Tamarit, C., \& Valverde, R. (2018). Institutional characteristics and managers' perceptions of accounting information: Impact on e-government use and organisational performance. Spanish Journal of Finance and Accounting/Revista Española de Financiación y Contabilidad, 47(3), 352-365. doi:https://doi.org/10.1080/ 02102412.2017 .1416743

de Jesus, M. A., \& Eirado, J. (2012). Relevance of accounting information to public sector accountability: A study of Brazilian federal public universities. Tékhne, 10(2), 87-98. doi:https://doi.org/10.1016/j.tekhne.2012.10.001

DeLone, W. H., \& McLean, E. R. (1992). Information systems success: The quest for the dependent variable. Information Systems Research, 3(1), 60-95.

Delone, W. H., \& McLean, E. R. (2003). The delone and mclean model of information systems success: A ten-year update. Journal of Management Information Systems, 19(4), 9-30. doi:https://doi.org/10.1080/07421222.2003.11045748

Eze, I. O. (2017). Corporate governance mechanisms and earnings management in Nigerian food product companies. Journal of Administrative and Business Studies, 3(1), 1-9. doi:https://doi.org/10.20474/jabs-3.1.1

Fahri, L. N. (2017). Pengaruh pelaksanaan kebijakan dana desa terhadap manajemen keuangan desa dalam meningkatkan efektivitas program pembangunan desa. Jurnal Publik: Jurnal Ilmiah Bidang Ilmu Administrasi Negara, 11(1), 75-88. doi:https://doi.org/10.29040/jap.v20i1.551

Galera, A. N., \& Bolívar, M. P. R. (2012). Adopting IPSAS to improve governmental accountability in Spain: An empirical study. International Journal of Critical Accounting, 4(5-6), 572-607.

Guthrie, J., Olson, O., \& Humphrey, C. (1999). Debating developments in new public financial management: The limits of global theorising and some new ways forward. Financial Accountability \& Management, 15(3-4), 209-228. doi:https:// doi.org/10.1111/1468-0408.00082

Ilias, A., Razak, M. Z. A., \& Rahman, R. A. (2015). The quality of non-financial information on internet business reporting for malaysian Public Listed Companies (PLCS). International Journal of Business and Administrative Studies, 1(4), 165-175. doi:https://doi.org/10.20469/ijbas.10005-4

Ismail, N. A., \& King, M. (2014). Factors influencing the alignment of accounting information systems in small and medium sized malaysian manufacturing firms. Journal of Information Systems and Small Business, 1(1-2), 1-20.

Jingsi, X. (2017). Network governance of haze in Shenyang. Journal of Advanced Research in Social Sciences and Humanities, 2(6), 371-376. doi:https://doi.org/10.26500/jarssh-02-2017-0605

Mancini, D., Vassen E, H. J., \& Dameri, R. P. (2013). Accounting information system for decision making. Berlin, Germany: Springer.

McLeod, J., Raymond. (2007). Management information systems. New York, NY: Pearson Prentice Hall.

McPhee, I. (2006). Financial management in the public sector how accrual accounting enhances governance and accountability. Retrieved from https://bit.1y/3fGi9z7

Media Rakyat Desa. (2015). Kejelasan dana desa dalam anggaran pendapatan dan belanja negara. Retrieved from https: // bit.ly/2TOEbmu

Negara, L. A., Keuangan, B. P., \& Pembangunan, R. (2000). Akuntabilitas dan good governance, modul 1-5, modul sosialisasi sistem Akuntabilitas Kinerja Instansi Pemerintah (AKIP). Jakarta, Indonesia: Lan BPKP RI.

O'brien, J. A., \& Marakas, G. (2005). Introduction to information systems. London, UK: McGraw-Hill, Inc.

Prudhomme, R. (1991). Information technology and the future of the city. OECD Observer, 2(6), 13-17.

Ramdhani, A. (2015). Effect the quality of accounting information systems and the effectiveness of internal control on financial reporting quality. Research Journal of Finance and Accounting, 6(6), 143-152.

Riant, N. D. (2004). Kebijakan publik, formulasi, implementasi, dan evaluasi. Jakarta, Indonesi: Elex Media Komputindo kelompok Gramedia.

Sačer, M., Ivana, \& Oluić, A. (2013). Information technology and accounting information systems' quality in Croatian middle and large companies. Journal of Information and Organizational Sciences, 37(2), 117-126.

Tsai, M. S., \& Tsai, M. C. (2017). The influence of loyalty, participation and obedience on organizational citizenship behavior. International Journal of Business and Economic Affairs, 2(1), 67-76. doi:https://doi.org/10.24088/ijbea-2017-21009

Warren, S., C, Reeve, M., J, \& Fess, E., P. (1999). Financial and managerial accounting. New York, NY: International Thomson Publishing. 